\title{
Income management strategies of older couples in Canada
}

\author{
Christine Laporte \\ Statistics Canada* \\ christine.laporte@statcan.gc.ca \\ Grant Schellenberg \\ Statistics Canada* \\ grant.schellenberg@statcan.gc.ca
}

\begin{abstract}
In this study, the income management strategies of Canadian couples are examined using data from the 2007 General Social Survey. The extent to which "older" couples, in which at least one spouse or partner is aged 45 or older, employ an allocative, pooled, or separate strategy is explored. Results show that the income management strategies used by these couples are correlated with relationship characteristics, such as common-law status, duration of relationship, and presence of children. As well, the likelihood of using a separate approach is positively correlated with levels of educational attainment and with the amount of income received by wives or female partners.
\end{abstract} Keywords: income management, intra-household allocation, older couples.

\section{Résumé}

La présente étude examine les stratégies de gestion du revenu des couples canadiens dont au moins un des conjoints ou partenaires est âgé de 45 ans et plus à l'aide des données de l'Enquête sociale générale de 2007. L'objectif est de déterminer dans quelle mesure les couples optent pour l'allocation, la mise en commun ou la séparation des revenus. Les résultats révèlent que les stratégies de gestion du revenu adoptées par les couples sont liées aux caractéristiques de la relation, dont l'union libre, la durée de la relation et la présence d'enfants. En outre, la probabilité de séparer les revenus est liée positivement au niveau de scolarité et au montant $d u$ revenu de la femme.

Mots-clés : gestion du revenu, allocation intra-ménage, couples.

* The views and opinions expressed in this article are those of the authors and do not reflect the position of Statistics Canada. 


\section{Introduction}

The last 30 years have witnessed substantial changes in the characteristics of Canadian families. Common-law unions have become more prevalent, the number of Canadians experiencing a divorce in their lifetime has increased, and blended or mixed families are more numerous than they were in the past. Labour market characteristics of families have also changed, reflecting the widespread entry of women into the paid labour force and their increasing contribution to family incomes. Attitudes regarding the roles of women and men in the labour force and in the home have also changed (Crompton et al. 2003). These developments have led researchers in a number of disciplines to re-examine the economic behaviours of families-how they make decisions about employment and consumption, how they balance paid and unpaid work, how they organize their income, and so on.

Although policymakers often assume that family decisions follow the unitary model à la Becker (1981), sociologists, economic psychologists, feminist economists, and, now, economists in general agree that such decisions and outcomes are shaped by intra-household negotiations between family members, particularly partners in married and common-law couples. Negotiations are influenced by factors such as the strength of each partner's bargaining position, expectations regarding the permanence of the relationship, and the balance between self-interest and collective interests.

In this paper, data from the 2007 General Social Survey (GSS) are used to examine the income management strategies of older Canadian couples, that is, couples in which at least one spouse or partner is aged 45 or older. We examine the extent to which couples use an allocative strategy of income management, in which one spouse or partner manages the couple's income and allocates a share to the other; a pooled strategy, in which both spouses or partners pool their incomes, with each taking out what he or she needs; or a separate strategy, in which spouses or partners keep their incomes partially or completely separate. The demographic and financial characteristics associated with these strategies are examined, and the extent to which observable characteristics account for the marked differences in the strategies used by married couples and common-law couples is estimated.

This study provides a useful complement to recent qualitative studies on this issue, estimating the incidence and correlates of income management strategies across a representative sample of the population. Furthermore, the analysis uses a more complete set of socioeconomic variables than is often available in quantitative studies. For example, Vogler et al. (2006), as well as Heimdal and Houseknecht (2003), document differences in the income management strategies of married and common-law couples, but are not able to determine the extent to which this reflects any systematic differences in the duration of these relationships, or in the presence or parentage of children. Other studies focus on either married (Treas 1993) or common-law couples (Winkler 1997; Elizabeth 2001). Consequently, the objective of this analysis is to examine the socioeconomic covariates associated with income management strategies, using a large, nationally representative survey that contains more complete information on respondent characteristics than has been available to date. Issues of gender inequality and power relationships, which are the focus of many studies of income management, are beyond the scope of this analysis. 


\section{Literature review}

Economists have been grappling with economic behaviour at the household level for many years. The traditional economic approach — the unitary model - mostly extends individual models of economic behaviour to households (Samuelson 1956; Becker 1973, 1981). The unitary model assumes that a household acts as a single decision-making unit, maximizing a single household utility function, subject to a single budget constraint. The model also imposes important restrictions, such as income pooling, whereby only total exogenous family income (and not its distribution across household members) matters for labour supply and consumption decisions, and provides for symmetry in the cross-wage effects on the labour supply of each household member, whereby a change in the wife's labour supply following a change in her husband's wage will be equal to the change in the husband's labour supply following a change in his wife's wage. Both income pooling and symmetry restrictions have been strongly rejected in empirical studies (Phipps and Burton 1996; Fortin and Lacroix 1997). The model has also been criticized on the grounds that it leaves no room for determining the intra-household allocation of consumption and labour supply. As Phipps and Burton summed up, the unitary model “... ignores the rather obvious fact that the family is made up of individuals with unique tastes and preferences who may or may not always agree-who may or may not have equal powers—who may or may not be equally well off" (1995: 179).

Partly for these reasons, new approaches have been developed based on individual preferences which use game theory (e.g., Chiappori 1988; Kooreman and Kapteyn 1990; McElroy 1990). However, it is the collective model of Chiappori (1992) that has opened the "black box" of family economic behaviour. In the collective model, family members are characterized as having their own preferences and interests, and bargaining is assumed to take place among household members. The bargaining process is influenced by a sharing rule, with the model assuming only that bargaining outcomes result in Pareto-efficient allocations of household resources. The model does not impose restrictions such as income pooling or symmetry of cross-wage effects. While the unitary model has been rejected in empirical studies, the collective model could not be rejected on the basis of either expenditure (Bourguigon et al. 1993) or labour supply (Fortin and Lacroix 1997) data.

The themes of intra-household negotiation and bargaining evident in collective models proposed by economists are also central themes in other disciplines. For example, some consumer researchers argue that women's entry into the paid labour force and their receipt of earnings have strengthened women's bargaining position within the home and changed the way that consumption decisions are made. Belch and Willis (2002) report that women within couples now play a greater role in the purchase of automobiles, family vacations, and insurance and financial services than they did in the mid-1980s and that decisions in these product areas have shifted from a husband-dominated process to a joint decision-making process. Intra-household negotiation and differences in power, material conditions, and risk are central themes in feminist research as well. The extent to which the entry of women into the paid labour has resulted in a renegotiation of household issues, such as domestic labour, work-family balance, child care, and income management, is a central theme in the literature (Tichenor 2005; Vogler 2005). 
Finally, economic psychology analyzes who makes the decisions and what characterizes the decision-making process within the family. In this field, income pooling is a subtle matter: couples may agree to pool income but their spending from the joint account may depend on who is earning the money. This definition differs from the unitary economic model, where consumption (and labour) decisions are independent of the distribution of income. Bonke and Browning (2009) tried to close the gap between economics and economic psychology using information on the assignment of expenditures (who bought the goods for whom). They found that distribution of consumption does depend on the distribution of income for households that declared not pooling their income, but this result is not found for pooling households.

Organization of income is one issue within this broader theme of household economic behaviour and intra-household negotiation. In the 1980s, Jan Pahl conceptualized (1986) and applied a four-part income management classification, capturing gradations of control over income exercised by spouses or partners (Heimdal and Houseknecht 2003). Pahl's typology of income management includes: (1) the whole wage system; (2) the housekeeping allowance system, in which one spouse or partner maintains control over the household budget and allocates a share or set amount to the other; (3) the pooled or shared management system, in which income is put into a common pot and used as needed by both spouses or partners; and (4) the independent management system, in which spouses or partners maintain separate control over their incomes and how they are spent.

Other qualitative and survey-based studies have also focused on the prevalence of allocative, pooled, and separate-income management strategies (Vogler and Pahl 1993; Burgoyne and Morison 1997; Burgoyne et al. 2007). It should be noted that these strategies do not tell us about how equitably income and expenses are shared between spouses or partners. For example, the relative size of a spouse or partner's share of income under the allocative approach is not specified, nor is there any guarantee that spouses or partners using a pooled strategy have equal access to funds, or draw comparable amounts for personal expenditures. Similarly, spouses or partners who separate their income may or may not contribute equally (or equitably) to expenses. Ashby and Burgoyne (2008) underscore the complexity of the issue, noting that couples that partially or completely separate their incomes perceive and handle money in a variety of ways (also see Vogler et al. 2006: 478). In short, broad categories do not capture the complex and varied ways in which couples manage their finances.

These caveats noted, responses to the income management question are suggestive of the degree of independence that individuals within couples exercise over their income. Tracking 42 couples over the first year of marriage, Burgoyne et al. found that "those choosing more separation in money matters did so in order to maintain their financial identity and autonomy" (2007: 214). Similarly, Vogler states that individuals who use separate-income strategies "...tend to operate as two autonomous individuals each with their own separate accounting systems who then exchange goods and services between them on the basis of market-like relationships" (2005: 12). ${ }^{1}$

1. Similarly, in terms of the operation of these strategies, Vogler et al. review the literature and suggest that couples using a pooled approach seek "...to achieve equality of outcomes, in the sense of equal control over and access to joint money, even though they may make very different financial contributions to the pool," while couples using a 
A range of characteristics have been associated with the income management strategies used by couples, and these can be broadly organized into three themes.

\section{Demographic characteristics}

Several studies document the correlation between demographic characteristics of couples and the likelihood of using pooled or separate approaches to income management. Marital status is among these demographic characteristics, as common-law couples are more likely than married couples to use a separate approach (Heimdal and Houseknecht 2003; Woolley 2003; Vogler 2005). A number of possible explanations have been advanced for this. Expectations regarding the permanence of the relationship may be lower among common-law than married couples, with incomes kept separate to protect self-interests in the event of break-up. The values espoused by individuals who self-select into common-law unions - such as individualism, personal autonomy, and equality of partners' contributions - may also contribute to the separation of income (Brines and Joyner 1999; Burgoyne et al. 2006). Laws regarding the treatment of joint property are another consideration (Treas 1993; Heimdal and Houseknecht 2003).

Several studies show that couples in which one or both partners have been previously divorced are more likely than others to use a separate approach to income management (Treas 1993; Heimdal and Houseknecht 2003; Woolley 2003; Yodanis and Lauer 2007a). Prior divorce may lower expectations of permanence in the current relationship and may also increase the complexity of familial and financial arrangements — such as the payment or receipt of child support-making the separation of income more practical on a day-to-day basis.

Duration of the relationship is another factor. The separate approach is less prevalent (and the pooled approach more prevalent) among couples in longerterm relationships (Treas 1993; Winkler 1997). This may reflect increased expectations of permanence, the acquisition of common goods over time (Burgoyne et al. 2007), or increased likelihood of children being born to the couple (Treas 1993; Winkler 1997). The presence of children born to both partners is also positively correlated with income pooling (Winkler 1997; Heimdal and Houseknecht 2003).

Finally, a significant, but weak, relationship is often found between age and income management strategies. For example, Treas (1993) found a negative, but weak, relationship between the wife's age and the likelihood of using separate bank accounts. Similarly, in their bivariate results, Bonke and Uldall-Poulsen (2007) showed that income pooling is least prevalent among couples in their twenties, but that it varies by about 1 to 4 percentage points across couples in their thirties, forties, and fifties. Vogler et al. (2006) find a positive correlation between age and independent income management among male respondents but not among female respondents or among all respondents. As well, Yodanis and Lauer (2007a) find a significant, but weak, correlation between age and income management strategies. Consequently, while younger individuals are often in the types of relationships in which separate-income strategies are used (i.e., common-law union, shorter duration, without children), the effect of age per se appears to be weak relative to the effect of other characteristics.

separate approach " ... are much more likely to define equality in terms of equal inputs, in the sense that both partners make equal contributions to collective expenditure ('going 50/50') despite often having very different levels of income" (2006: 459). 


\section{Income and education}

Some studies have examined the correlation between income management strategies and the income characteristics of couples. Treas (1993) addresses this in terms of absolute income levels, suggesting that the correlation with income management strategies may run in either direction. On the one hand, higher-income couples may be more likely to use separate accounts in order to avoid the inconvenience of sharing. On the other hand, they may be more likely to pool their income if there is less concern about "free riding" or "spendthrifts" when resources are more plentiful. Treas finds that the likelihood of maintaining separate accounts is positively correlated with couples' incomes. Heimdal and Houseknecht (2003) observe the same in the Swedish portion (but not in the American portion) of their sample, while Bonke and Uldall-Poulsen (2007) do not find a consistent pattern across household income quintiles. Vogler et al. (2006) do not include household income in their model, but find that the likelihood of separating income is higher among managerial or professional than among "working class" couples.

Another approach to resources is the relative contribution of each partner to the couple's income. Certainly the circumstances for maintaining separate finances do not exist when only one spouse receives income. Beyond that, Bonke and Uldall-Poulson (2007) suggest that an unequal distribution of income within couples may increase the likelihood of separating income when spouses are "egoistically inclined" or the likelihood of pooling income when they are "altruistically inclined." Bonke and Uldall-Poulson find that income pooling is not strongly associated with spouses' income contributions. This is also the case with Heimdal and Houseknecht (2003). In contrast, Yodanis and Lauer (2007a) hypothesize that when the relative economic contributions of spouses approach parity couples will be more likely to use a pooled, rather than an allocative, approach to income management. Their results are consistent with this view.

Net of income, Treas (1993) finds that higher levels of educational attainment among women are positively associated with maintaining separate accounts. However, considering relative levels, Bonke and Uldall-Poulson (2007) do not find a significant correlation between spouses' relative levels of education and income management strategies.

\section{Attitudinal characteristics}

Finally, some researchers have examined the correlation between income management strategies and other aspects of relationships, such as normative attitudes and personal values. For example, normative attitudes regarding gender roles are often based on how strongly respondents agree or disagree with declarative statements. Vogler et al. (2006) find that more traditional "attitudes to breadwinning" are correlated with allocative income management strategies; Yodanis and Lauer (2007a) report a similar finding. ${ }^{2}$ However, the measure of "traditional gender ideology" used by Heimdal and Houseknecht (2003) is not significantly correlated with income management strategies among either the Swedish or American portions

2. For example, Vogler et al. operationalize "attitudes to breadwinning" on the basis of respondents' degree of (dis)agreement with statements such as "A man's job is to earn the money; a woman's is to look after the home and family" (2006: 463). 
of their sample. Considering other values, Burgoyne et al. (2007) report that “... perceived ownership of income and other assets" and a desire to maintain financial identity and autonomy are positively associated with the separation of income.

\section{Data source and methodology}

Data for this paper were drawn from Statistics Canada's 2007 General Social Survey (GSS). The target population for the 2007 GSS was all persons 45 years of age and over residing in Canada, excluding residents of Nunavut, the Yukon, and the Northwest Territories, and full-time residents of institutions. The 2007 GSS was completed by 23,404 respondents, of whom 12,854 were living with a spouse or common-law partner ${ }^{3}$ at the time of the survey. Excluded from this group were respondents for whom proxy responses were provided by another household member, ${ }^{4}$ who did not provide useable responses to the question regarding income management strategies, ${ }^{5}$ or who did not provide complete information on the independent variables in this analysis. ${ }^{6}$ Households in which family members aside from the couple received income were also excluded from the analysis. ${ }^{7}$ This was done to remove the effects of income strategies adopted for managing the income received by parents, children, and other members, and focus solely on the strategies for managing the income of husbands and wives. A final sample of 9,489 respondents is used for the analysis.

In terms of the age limitations of the data, results from other studies suggest a significant, but weak, correlation between age and income management strategies. We were unable to identify any studies that tested for interaction effects between age and other variables, such as common-law status. In spite of the age limitation faced, the analysis yields robust results regarding the socioeconomic characteristics associated with income management strategies among "older" Canadians.

2007 GSS respondents were asked:

Which statement best describes how your household income is organized?

- You manage all the money and give your spouse/partner their share.

- Your spouse/partner manages all the money and gives you your share.

- You pool all the money and each takes out what he/ she needs.

- You pool some of the money and keep the rest.

- You keep your own money separate.

- Other.

3. Couples are defined as partners of opposite sex only. Same-sex couples were excluded from the analysis because of their small sample size (73 same-sex couples).

4. Proxy responses were provided in 618 cases, or 2.6 per cent of the sample.

5. This includes 63 respondents who reported that they use strategies "other" than the five responses listed in the paper and 380 respondents who either did not know what type of strategy they used or did not answer the question. The incidence of item non-response on the question was comparable to that on standard questions, such as educational attainment.

6. However, note that respondents who did not answer GSS questions regarding income were flagged and retained in the analysis.

7. This resulted in the exclusion of 218 cases in which adult children (aged 25 or older) received income and 2,261 cases in which other family members, such as children aged 15 to 24 or extended-family members, received income. The inclusion of these cases would have made it impossible to measure the relative income contribution of the spouses in the sample for this study — a key variable in the literature. 
For this analysis, the above categories are aggregated into three groups. The first two categories are combined because they capture the same underlying strategy identified as allocative. The third category is treated as a distinct group that is identified as the pooled strategy. And the fourth and fifth categories are combined into a single group identified as the separate strategy. ${ }^{8}$

The distribution of respondents across the three income management categories (as well as across the five original response categories) is shown in Table 1. Of the respondents who use the separate approach to manage their income (22.9 per cent), about two-thirds (i.e., 15.3/22.9) reported that they and their partner "...keep [their] own money separate," while about one-third (i.e., 7.6/22.9) stated that they and their partner "...pool some of the money and keep the rest." In short, complete separation of income is more prevalent than partial separation within this group. In this respect, the conceptual distance between the pooled and separate approaches to income management is larger than it would have been had most respondents partially separated their income.

It is important to note that the 2007 GSS surveyed individuals rather than couples, with information collected from only one spouse or partner. Whether the other spouse or partner agrees with the respondent's assessment of the couple's approach to income management cannot be determined. In the aggregate, the responses provided by men and women are very similar. About 8 per cent of both male and female respondents stated that the husband or male partner manages the couple's money and gives his wife or female partner her share, and about 12 per cent of male and female respondents stated that the wife or female partner manages the income and gives her husband or male partner his share (Table 1).

Table 1. Income management strategies used by individuals aged 45 or older, by gender, Canada, 2007.

\begin{tabular}{|c|c|c|c|c|c|c|}
\hline \multirow[b]{2}{*}{ Approaches } & \multicolumn{6}{|c|}{ Male respondents Female respondents All respondents } \\
\hline & $\begin{array}{l}\text { percentage } \\
\text { distribution }\end{array}$ & $\begin{array}{l}\text { tandar } \\
\text { error }\end{array}$ & $\begin{array}{l}\text { percentage } \\
\text { distribution }\end{array}$ & $\begin{array}{l}\text { tandarc } \\
\text { error }\end{array}$ & $\begin{array}{l}\text { percentage } \\
\text { distribution }\end{array}$ & $\begin{array}{l}\text { tandard } \\
\text { error }\end{array}$ \\
\hline Allocative approach - Tota & $1 \quad 20.9$ & 0.6 & 19.5 & 0.6 & 20.3 & 0.5 \\
\hline $\begin{array}{l}\text { Female allocates to } \\
\text { male }\end{array}$ & 12.2 & 0.5 & 11.6 & 0.5 & 11.9 & 0.4 \\
\hline $\begin{array}{l}\text { Male allocates to } \\
\text { female }\end{array}$ & 8.8 & 0.5 & 7.9 & 0.5 & 8.4 & 0.3 \\
\hline Pooled approach - Total & 57.7 & 0.7 & 55.9 & 0.7 & 56.9 & 0.6 \\
\hline Separate approach - Total & 21.4 & 0.6 & 24.6 & 0.6 & 22.9 & 0.4 \\
\hline $\begin{array}{l}\text { Partially separate, some } \\
\text { pooled }\end{array}$ & 7.1 & 0.4 & 8.2 & 0.5 & 7.6 & 0.3 \\
\hline $\begin{array}{l}\text { Keep their money } \\
\text { separate }\end{array}$ & 14.2 & 0.6 & 16.4 & 0.6 & 15.3 & 0.4 \\
\hline
\end{tabular}

Note: Percentages may not add to total because of rounding.

Source: General Social Survey, 2007.

8. Again, only 63 respondents reported using another type of system, and these respondents have been excluded from the analysis. The categorization used in this study is more detailed than the two-category classification used in a number of studies. Vogler et al. (2008), Treas (1993), and Heimdal and Houseknecht (2003) combined the allocative and pooled strategies into a single category. In part, this was done for reasons of sample size, but Vogler et al. also argued that the allocative and pooled strategies are "...systems in which money is constructed as collectively owned and couples operate more or less as single economic units." This is different from the separate strategy, which reflects "individualized systems" (2008: 120). 
The proportions of male and female respondents reporting that they use a pooled or separate approach to income management are within 2 to 3 percentage points.

\section{Independent variables and descriptive results}

This analysis includes a broad set of socioeconomic characteristics drawing on the information that respondents provide about themselves and about their spouse or partner. Respondents' sex and age and the age of their spouse or partner are included. The immigration status of both the respondent and his or her spouse or partner are included on the grounds that income management strategies vary across world regions, potentially resulting in differences between individuals born in Canada and individuals born abroad. ${ }^{9}$ The base model includes a dummy variable for each spouse or partner (Canadian-born=0, immigrant=1), and a second model includes four dummy variables capturing the immigration statuses of both spouses or partners in combination. ${ }^{10}$

Information regarding the relationship itself is included. Distinction is made between individuals in common-law and marital unions, with the expectation that the former are more likely to separate their incomes, for the reasons discussed above. The duration of the current relationship and a dummy variable identifying respondents who have been married before are also included. Consistent with the literature, it is expected that the separation of income will be correlated with shorter relationships and with prior marriages. The characteristics and history of the family in which respondents currently reside are included. By definition, all respondents currently live with a spouse or common-law partner. In addition, the following are identified: (i) individuals who have previously had children with their current spouse or partner, but who are no longer residing with those children (i.e., empty-nesters); (ii) individuals who have not previously had children with their current spouse or partner and have no children residing with them (i.e., couple with no children); (iii) individuals living with children born to both members of the couple (i.e., couple with children); and (iv) individuals living with children born to one member of the couple (i.e., other couple). The presence of children (now or in the past) is expected to be positively correlated with the pooled approach to income management.

With regard to education and income, the level of education of the respondent and that of his or her spouse or partner are included, broadly defined as the presence of a post-secondary credential. The base model includes a dummy variable for each spouse or partner (no post-secondary credential=0, post-secondary credential=1). The second model also includes the wife's level of educational attainment relative to that of her husband. ${ }^{11}$ Treas (1993) suggests that additional

9. 2002 ISSP data show that the "allocative approach" is used by 3 per cent to 5 per cent per cent of couples in Sweden, Finland, and Norway, by about 15 per cent to 25 per cent of couples in "Anglo" countries (the United States, United Kingdom, Ireland, Australia, and New Zealand), by about 45 per cent to 55 per cent of couples in Brazil, Mexico, and Chile, and by 70 per cent of couples in the Philippines and Japan. Canada is not included in the 2002 ISSP.

10. That is: both partners born in Canada (reference group); husband born in Canada and wife immigrated; husband immigrated and wife born in Canada; and both partners immigrated.

11. Since, in the GSS, education is a categorical variable, the wife or female partner's education relative to that of her husband or male partner is defined as the wife or female 
years of education may enhance individuals' money management skills, thereby increasing their capacity to maintain separate accounts, or may strengthen their bargaining position within the household and increase their capacity to maintain separate incomes, if so preferred. The income level of each partner is included in the base model, while the second model also includes the wife's level of income relative to the husband's. ${ }^{12}$

Finally, a variable combining the respondent's place of residence (defined as residing in Quebec or residing elsewhere in Canada) and the main language which the respondent uses at home (defined as English, French, or other) is included. This yields six categories: English outside of Quebec (reference group); French outside of Quebec; others outside of Quebec; English in Quebec; French in Quebec; and others in Quebec.

Distribution of the sample across these characteristics, and cross-tabulations with income management strategies are shown in Table 2 . The vast majority of individuals in the sample (89 per cent) are married, while 11 per cent are in commonlaw unions. There is a 34-percentage-point difference in the share of married and common-law individuals using a separate-income strategy (at 19 per cent and 53 per cent). Most individuals in the sample have been in their relationship for more than 20 years (71 per cent), while relatively few have been so for less than five years (6 per cent). There is a strong bivariate relationship between relationship duration and use of separate-income strategies. About half of the sample (48 per cent) are "empty-nesters," about one-quarter (27 per cent) live with a spouse or partner with whom they have never had children, and about one-fifth (22 per cent) live with their spouse or partner and children born to both. Only a small portion of the sample resides in blended families ( 3 per cent); it is interesting to note that the use of the separate-income strategy is quite prevalent among this group (at 40 per cent). About one-fifth of the sample ( 22 per cent) has been previously married; consistent with the literature, separate-income strategies are prevalent among this group. In terms of income, there is not a noticeable bivariate correlation between the husband or male partner's income and income management strategies (with the exception of the few who reported no income), while the use of separateincome strategies are positively correlated with the income of the wife or female partner. Finally, there are significant differences in the use of separate-income strategies among respondents residing in Quebec and respondents residing elsewhere in Canada, and among respondents who speak English, French, or other languages in the home.

partner's level of education minus the husband or male partner's level of education.

12. The GSS includes a continuous variable on respondent personal income, a categorical variable on household income and the number of income recipients in the household. From this information, it was possible to derive income for both the wife or female partner and the husband or male partner. Using lower bounds and middle points of the household income categories gave very similar regression results. The wife or female partner's income relative to her husband or male partner's is defined as the difference between wife or female partner's income and husband or male partner's income. 
Table 2. Descriptive statistics (\%).

\begin{tabular}{|c|c|c|c|c|}
\hline \multirow{2}{*}{ Variables } & \multirow{2}{*}{ Mean } & \multicolumn{3}{|c|}{$\begin{array}{l}\text { Financial strategies } \\
\end{array}$} \\
\hline & & Allocative & Pooled & Separate \\
\hline \multicolumn{5}{|l|}{ Gender TOTAL } \\
\hline Female & 46.8 & 20.9 & 57.7 & 21.4 \\
\hline Male & 53.2 & 19.5 & 55.9 & 24.6 \\
\hline \multicolumn{5}{|l|}{ Immigrant status - Male } \\
\hline Canadian born & 76.8 & 19.5 & 55.9 & 24.6 \\
\hline Immigrant & 23.2 & 22.7 & 60.2 & 17.1 \\
\hline \multicolumn{5}{|l|}{ Immigrant status - Female } \\
\hline Canadian born & 77.9 & 19.7 & 56.0 & 24.2 \\
\hline Immigrant & 22.1 & 22.3 & 59.8 & 18.0 \\
\hline \multicolumn{5}{|l|}{ Marital status } \\
\hline Common law & 10.9 & 15.1 & 32.0 & 52.8 \\
\hline Married & 89.1 & 20.9 & 59.9 & 19.2 \\
\hline \multicolumn{5}{|l|}{ Duration of actual relation } \\
\hline Less than 5 years & 5.6 & 15.6 & 32.0 & 52.4 \\
\hline 5 to 9 years & 6.3 & 13.9 & 40.7 & 45.3 \\
\hline 10 to 19 years & 16.7 & 19.8 & 51.8 & 28.4 \\
\hline More than 20 years & 71.4 & 21.3 & 61.4 & 17.3 \\
\hline \multicolumn{5}{|l|}{ Family type } \\
\hline Couple, no children & 26.6 & 17.9 & 44.5 & 37.5 \\
\hline Empty nesters & 48.3 & 21.3 & 62.0 & 16.6 \\
\hline Couple with children & 22.5 & 20.9 & 62.1 & 17.0 \\
\hline \multirow{2}{*}{\multicolumn{5}{|c|}{ Previously married }} \\
\hline & & & & \\
\hline No & 77.6 & 20.9 & 60.4 & 18.7 \\
\hline Yes & 22.4 & 18.2 & 44.5 & 37.3 \\
\hline \multicolumn{5}{|l|}{ Education-Male } \\
\hline Postsecondary & 55.0 & 18.4 & 57.6 & 24.0 \\
\hline No postsecondary & 43.0 & 22.4 & 56.4 & 21.2 \\
\hline Unknown & 1.5 & 28.5 & 42.9 & 28.6 \\
\hline \multicolumn{5}{|l|}{ Education-Female } \\
\hline Postsecondary & 50.0 & 17.4 & 56.4 & 26.1 \\
\hline No postsecondary & 48.0 & 23.1 & 57.7 & 19.2 \\
\hline \multirow{2}{*}{\multicolumn{5}{|c|}{ Income-Male }} \\
\hline & & & & \\
\hline No income & 1.3 & 37.9 & 52.9 & 9.2 \\
\hline$\$ 1$ to $\$ 19,999$ & 9.6 & 21.0 & 56.2 & 22.8 \\
\hline$\$ 20,000$ to $\$ 39,999$ & 23.0 & 21.4 & 55.5 & 23.1 \\
\hline$\$ 40,000$ to $\$ 59,999$ & 18.2 & 18.9 & 55.1 & 26.0 \\
\hline$\$ 60,000$ to $\$ 100,000$ & 15.8 & 18.8 & 56.5 & 24.7 \\
\hline Greater than $\$ 100,000$ & 11.6 & 16.7 & 59.6 & 23.6 \\
\hline \multirow{2}{*}{\multicolumn{5}{|c|}{ Income-Female }} \\
\hline & & & & \\
\hline No income & 9.6 & 35.2 & 58.5 & 6.3 \\
\hline$\$ 1$ to $\$ 19,999$ & 26.5 & 22.2 & 58.4 & 19.4 \\
\hline$\$ 20,000$ to $\$ 39,999$ & 20.5 & 18.0 & 55.4 & 26.6 \\
\hline$\$ 40,000$ to $\$ 59,999$ & 11.5 & 14.7 & 51.1 & 34.2 \\
\hline$\$ 60,000$ to $\$ 100,000$ & 7.9 & 12.5 & 57.5 & 30.0 \\
\hline Greater than $\$ 100,000$ & 5.5 & 13.5 & 55.6 & 31.0 \\
\hline Unknown & 18.5 & 21.0 & 59.2 & 19.8 \\
\hline \multicolumn{5}{|l|}{ Relative income } \\
\hline Male's income $=$ Female's income & 18.6 & 16.6 & 55.4 & 28.0 \\
\hline Male's income $<$ Female's income & 13.6 & 17.3 & 53.7 & 29.0 \\
\hline Male's income $>$ Female's income & 46.3 & 21.6 & 57.5 & 20.9 \\
\hline Both incomes unknown & 21.5 & 22.3 & 58.8 & 18.9 \\
\hline Province & & & & \\
\hline Rest of Canada & 75.0 & 21.1 & 59.0 & 19.9 \\
\hline Quebec & 25.0 & 17.8 & 50.5 & 31.7 \\
\hline Language at home & & & & \\
\hline French & 23.5 & 17.2 & 50.3 & 32.5 \\
\hline English & 67.0 & 20.4 & 58.6 & 21.1 \\
\hline Other & 9.5 & 27.1 & 61.3 & 11.6 \\
\hline
\end{tabular}

Note: There are 9,489 observations in the sample. 


\section{Empirical strategies and results}

Our multivariate analysis proceeds in three steps. First, results from a multinomial logit model are presented, in which the dependent variable is comprised of the three income management strategies. A second model is run on the same dependent variable, but both absolute and relative levels of education and income are included. This makes it possible to assess whether income management strategies are correlated with the absolute or relative characteristics of individuals-an issue that is central to the intra-household bargaining perspective on economic behaviour. Finally, differences in the use of separate-income strategies among common-law and married couples are examined by means of a Blinder-Oaxaca decomposition. All models are calculated using bootstrap weights to correct variance estimates for survey design. Results are shown as "marginal effects," along with the standard errors of the estimates and levels of statistical significance.

\section{Multivariate regressions}

Most coefficients in the analysis yield results consistent with expectations. Sex and age are two exceptions. The predicted probability of using a separate approach to income management is 2 percentage points higher among women than among men (Table 3). Given the data available from the GSS, one cannot determine whether this is attributable to how husbands and wives within the same couple perceive their finances, or whether this is attributable to other factors. A significant correlation between the age of the wife or female partner and the likelihood of using either a pooled or separate approach to income management was found as well. Again, no ready explanation can be found for this. Different categorizations of the age variables were used in earlier analyses but yielded similar results. ${ }^{13} \mathrm{Im}$ migration status is correlated with income management strategies; the probability of using a separate approach is almost 3 percentage points lower among male immigrants than among their Canadian-born counterparts. A similar result is found using the alternative specification of immigration status.

In terms of the characteristics of the relationship, a strong correlation is found between the duration of the relationship and income management strategies. Compared with individuals who have been in their relationship less than five years, those in relationships of 10 to 19 years are about 14 percentage points less likely to separate their income, while those in relationships of more than 20 years are almost 21 percentage points less likely to do so. Moreover, individuals in common-law unions are far more likely than those in legal marriages to separate their income-a difference of 15 percentage points—even after the duration of the relationship is taken into account.

The presence of children - either currently or previously residing with the couple-is correlated with income management practices. Compared with couples who have never had children, empty-nesters are less likely to separate their income

13. For example, one might hypothesize that receipt of Old Age Security benefits at age 65 provides elderly women with an independent, personal source of income over which they prefer retaining control, and thereby increases the propensity to use at least a partially separate approach to finances. However, a variable identifying women who were younger than age 65 and women who were older than age 65 did not provide support for this hypothesis. 
Table 3. Multinomial logit performed on income management strategies (base model).

\begin{tabular}{|c|c|c|c|c|c|c|}
\hline & \multicolumn{2}{|c|}{ Allocative } & \multicolumn{2}{|c|}{ Pooled } & \multicolumn{2}{|c|}{ Separate } \\
\hline & $\begin{array}{c}\text { marginal } \\
\text { effect }\end{array}$ & $\begin{array}{l}\text { standard } \\
\text { error }\end{array}$ & $\begin{array}{l}\text { marginal } \\
\text { effect }\end{array}$ & $\begin{array}{l}\text { standard } \\
\text { error }\end{array}$ & $\begin{array}{l}\text { marginal } \\
\text { effect }\end{array}$ & $\begin{array}{c}\text { standard } \\
\text { error }\end{array}$ \\
\hline Female & -0.009 & 0.011 & -0.014 & 0.027 & $0.023 *$ & 0.010 \\
\hline Male’s age & 0.000 & 0.001 & -0.002 & 0.002 & 0.001 & 0.001 \\
\hline Female's age & -0.001 & 0.001 & $-0.005 *$ & 0.003 & $0.002 *$ & 0.001 \\
\hline Male immigrant & 0.007 & 0.018 & 0.020 & 0.042 & $-0.027 \dagger$ & 0.015 \\
\hline Female immigrant & -0.011 & 0.017 & 0.006 & 0.039 & 0.006 & 0.016 \\
\hline Common-law & -0.012 & 0.019 & $-0.142 * *$ & 0.031 & $0.154 * *$ & 0.019 \\
\hline \multicolumn{7}{|c|}{ Duration of relation (less than 5 years) } \\
\hline 5 to 9 years & -0.033 & 0.022 & 0.054 & 0.035 & -0.021 & 0.030 \\
\hline 10 to 19 years & 0.019 & 0.025 & $0.116 * *$ & 0.045 & $-0.135 * *$ & 0.024 \\
\hline More than 20 years & 0.020 & 0.027 & $0.185 * *$ & 0.045 & $-0.205 * *$ & 0.026 \\
\hline \multicolumn{7}{|c|}{ Family type (couple, no children) } \\
\hline Empty nesters & 0.005 & 0.016 & $0.061 \dagger$ & 0.036 & $-0.066 * *$ & 0.015 \\
\hline Couple with children & 0.022 & 0.020 & $0.077 \dagger$ & 0.039 & $-0.099 * *$ & 0.017 \\
\hline Othe & 0.038 & 0.041 & 0.028 & 0.062 & $-0.066 *$ & 0.034 \\
\hline Previously married & 0.005 & 0.018 & -0.012 & 0.037 & 0.007 & 0.014 \\
\hline \multicolumn{7}{|l|}{ Education } \\
\hline \multicolumn{7}{|c|}{ Male (no postsecondary) } \\
\hline With postsecondary & $-0.027 *$ & 0.012 & 0.004 & 0.026 & $0.023 *$ & 0.009 \\
\hline Unknown education & $0.098 \dagger$ & 0.050 & -0.072 & 0.089 & -0.026 & 0.027 \\
\hline \multicolumn{7}{|c|}{ Female (no postsecondary) } \\
\hline With postsecondary & $-0.027 * *$ & 0.012 & -0.009 & 0.027 & $0.035 * *$ & 0.010 \\
\hline Unknown education & 0.048 & 0.047 & -0.034 & 0.087 & -0.014 & 0.026 \\
\hline \multicolumn{7}{|l|}{ Income } \\
\hline \multicolumn{7}{|c|}{ Male $(\$ 20,000$ to $\$ 39,999)$} \\
\hline Reports no income & $0.175 *$ & 0.075 & -0.024 & 0.113 & $-0.151 * *$ & 0.020 \\
\hline$\$ 1 \mathrm{t}$ & -0.013 & 0.019 & 0.009 & 0.046 & 0.004 & 0.018 \\
\hline$\$ 59,999$ & -0.011 & 0.017 & -0.004 & 0.034 & 0.016 & 0.015 \\
\hline 0 to $\$ 100,000$ & -0.010 & 0.019 & 0.005 & 0.039 & 0.006 & 0.015 \\
\hline r than $\$ 100,000$ & $0-0.021$ & 0.022 & 0.027 & 0.051 & -0.006 & 0.019 \\
\hline Income unknown & -0.010 & 0.032 & 0.023 & 0.078 & -0.012 & 0.028 \\
\hline \multicolumn{7}{|l|}{ Female (\$1 to \$19,999) } \\
\hline Reports no income & $0.135 * *$ & 0.041 & -0.016 & 0.067 & $-0.119 * *$ & 0.011 \\
\hline$\$ 20$ & $-0.035^{*}$ & 0.015 & -0.017 & 0.035 & $0.052 * *$ & 0.014 \\
\hline$\$ 40,000$ to $\$ 59,999$ & $-0.059 * *$ & 0.017 & -0.058 & 0.037 & $0.117 * *$ & 0.020 \\
\hline$\$ 60,000$ to $\$ 100,000$ & $-0.077 * *$ & 0.020 & -0.005 & 0.050 & $0.082 * *$ & 0.022 \\
\hline Greater than $\$ 100,000$ & $0-0.069 * *$ & 0.023 & -0.029 & 0.053 & $0.098 * *$ & 0.025 \\
\hline Income unknown & -0.015 & 0.031 & -0.008 & 0.081 & 0.023 & 0.028 \\
\hline \multicolumn{7}{|c|}{ Language (English in rest of Canada) } \\
\hline French in Quebec & $-0.043 * *$ & 0.013 & $-0.063 *$ & 0.025 & $0.106 * *$ & 0.013 \\
\hline $\begin{array}{l}\text { French in rest of } \\
\text { Canada }\end{array}$ & -0.039 & 0.032 & -0.028 & 0.071 & $0.068 *$ & 0.032 \\
\hline English in Quebec & 0.011 & 0.040 & -0.103 & 0.065 & $0.091 *$ & 0.036 \\
\hline $\begin{array}{l}\text { Other language in } \\
\text { Quebec }\end{array}$ & 0.020 & 0.063 & 0.016 & 0.137 & -0.036 & 0.042 \\
\hline $\begin{array}{l}\text { Other language in rest } \\
\text { of Canada }\end{array}$ & $0.056 \dagger$ & 0.034 & -0.026 & 0.063 & -0.030 & 0.022 \\
\hline
\end{tabular}

Note: $\dagger \mathrm{p}<0.1,{ }^{*} \mathrm{p}<0.05,{ }^{* *} \mathrm{p}<0.01$. Omitted categories in parentheses. 
(a difference of almost 7 percentage points) and more likely to pool it. Similarly, the likelihood of using a separate approach is lower among couples who have children currently residing with them, whether the children were born to both spouses or partners (a difference of 10 percentage points) or to only one of the spouses or partners (a difference of 7 percentage points). Finally, while other studies have reported that the separation of income is positively correlated with one or both spouses or partners having a prior marriage, this is not the case in the multivariate results. ${ }^{14}$

Education is correlated with the type of income management strategy used. The predicted probability of using a separate approach to income is higher among women and men who have post-secondary credentials than among their counterparts who do not (differences of about 4 percentage points and 2 percentage points, respectively). Conversely, men and women with post-secondary credentials are less likely than others to use an allocative system. When the education of wives relative to that of their husbands is included in the model, no significant correlations are observed (Table 4); this suggests that it is absolute levels of education that matter, rather than relative levels between the spouses.

Income management strategies are also correlated with income, particularly with that of wives. When one of the spouses or partners is reported to have no income, the likelihood that the couple uses an allocative approach is substantially higher-almost 18 percentage points among men (relative to men with incomes of $\$ 20,000$ to $\$ 39,999$ ) and almost 14 percentage points among women (relative to women with incomes of $\$ 1$ to $\$ 19,999) .{ }^{15}$ Aside from this correlation, income management strategies are not associated with the amount of income received by the husband or male partner. However, the likelihood of using a separate approach to income management is correlated with the income of the wife or female partner. The likelihood of using a separate approach to income is about 5 percentage points higher among wives or female partners with incomes of $\$ 20,000$ to $\$ 39,999$ and about 8 to 12 percentage points higher among wives or female partners with incomes over $\$ 40,000$ than among wives or female partners with incomes of $\$ 1$ to $\$ 19,999$. When the incomes of wives relative to their husbands' are included in the model, the variable is not significant (Table 4). As with educational attainment, it is the absolute level of income rather than relative level between spouses that is correlated with income management strategies.

The final variable in the analysis captures regional and linguistic characteristics of individuals. The reference group for this variable is Anglophones residing outside Quebec. ${ }^{16}$ Compared with this group, Francophones residing outside Quebec are significantly more likely to use a separate approach to income management (a difference of 7 percentage points) as are Francophones residing in Quebec (a difference of 11 percentage points). However, while this suggests that there

14. Among older couples, cohabitation (i.e., common-law status) may follow a previous marriage; this raises the possibility of overlap between these two variables. To assess this, the model was run with the common-law variable excluded and subsequently run with a variable combining common-law status and previous marriage. These specifications yielded the same result; that is, previous marriages remained insignificant.

15. Different reference categories were used for men and women on the income variable.

16. Dummy variables for all the provinces in Canada were used in an earlier version of the analysis, but yielded results similar to the results yielded by the "Quebec-Rest of Canada" dummy. The latter was retained in the model for the sake of parsimony and ease of presentation. 
Table 4. Multinomial logit on income management strategies (supplementary model).

\begin{tabular}{|c|c|c|c|c|c|c|}
\hline & \multicolumn{2}{|c|}{ Allocative } & \multicolumn{2}{|c|}{ Pooled } & \multicolumn{2}{|c|}{ Separate } \\
\hline & $\begin{array}{c}\text { marginal } \\
\text { effect }\end{array}$ & $\begin{array}{c}\text { standarc } \\
\text { error }\end{array}$ & $\begin{array}{c}\text { marginal } \\
\text { effect }\end{array}$ & $\begin{array}{l}\text { standarc } \\
\text { error }\end{array}$ & $\begin{array}{l}\text { marginal } \\
\text { effect }\end{array}$ & $\begin{array}{l}\text { standard } \\
\text { error }\end{array}$ \\
\hline \multicolumn{7}{|c|}{ Immigrant status (both Canadian-born) } \\
\hline $\begin{array}{l}\text { Immigrant male and } \\
\text { Canadian-born female }\end{array}$ & -0.010 & 0.021 & 0.025 & 0.051 & -0.015 & 0.018 \\
\hline $\begin{array}{l}\text { Canadian-born male } \\
\text { and immigrant female }\end{array}$ & -0.032 & 0.020 & 0.013 & 0.048 & 0.019 & 0.019 \\
\hline Both immigrant & 0.009 & 0.021 & 0.020 & 0.049 & $-0.029 \dagger$ & 0.017 \\
\hline \multicolumn{7}{|l|}{ Absolute education } \\
\hline \multicolumn{7}{|l|}{ Male (no postsecondary) } \\
\hline With postsecondary & -0.018 & 0.017 & -0.003 & 0.037 & $0.021 \dagger$ & 0.012 \\
\hline Unknown education & 0.092 & 0.300 & 0.038 & 0.558 & $-0.130 *$ & 0.066 \\
\hline \multicolumn{7}{|c|}{ Female (no postsecondary) } \\
\hline With postsecondary & $-0.038 *$ & 0.015 & 0.000 & 0.035 & $0.037 * *$ & 0.013 \\
\hline Unknown education & 0.033 & 0.266 & 0.092 & 0.656 & $-0.125 \dagger$ & 0.072 \\
\hline \multicolumn{7}{|c|}{ Relative education (Male's education > Female's education) } \\
\hline $\begin{array}{l}\text { Male's education = } \\
\text { Female's education }\end{array}$ & -0.016 & 0.015 & 0.017 & 0.035 & -0.002 & 0.013 \\
\hline $\begin{array}{l}\text { Male's education }< \\
\text { Female's education }\end{array}$ & 0.026 & 0.020 & -0.021 & 0.046 & -0.005 & 0.018 \\
\hline $\begin{array}{l}\text { Both education } \\
\text { unknown }\end{array}$ & -0.034 & 0.148 & -0.205 & 0.237 & 0.239 & 0.279 \\
\hline \multicolumn{7}{|l|}{ Absolute income } \\
\hline \multicolumn{7}{|c|}{ Male $(\$ 20,000$ to $\$ 39,999)$} \\
\hline Reports no income & $0.143 \dagger$ & 0.076 & 0.004 & 0.123 & $-0.147 * *$ & 0.021 \\
\hline$\$ 1$ to $\$ 19,999$ & -0.009 & 0.021 & 0.010 & 0.050 & -0.001 & 0.019 \\
\hline$\$ 40,000$ to $\$ 59,999$ & -0.012 & 0.017 & -0.008 & 0.036 & 0.019 & 0.015 \\
\hline$\$ 60,000$ to $\$ 100,000$ & -0.013 & 0.020 & -0.001 & 0.043 & 0.014 & 0.017 \\
\hline Greater than $\$ 100,000$ & -0.018 & 0.025 & 0.016 & 0.062 & 0.002 & 0.023 \\
\hline Income unknown & -0.085 & 0.056 & 0.069 & 0.165 & 0.016 & 0.058 \\
\hline \multicolumn{7}{|l|}{ Female (\$1 to \$19,999) } \\
\hline Reports no income & $0.128 * *$ & 0.040 & -0.011 & 0.067 & $-0.117 * *$ & 0.011 \\
\hline$\$ 20,000$ to $\$ 39,999$ & $-0.033 *$ & 0.016 & -0.014 & 0.037 & $0.047 * *$ & 0.015 \\
\hline$\$ 40,000$ to $\$ 59,999$ & $-0.057 * *$ & 0.019 & -0.052 & 0.041 & $0.109 * *$ & 0.022 \\
\hline$\$ 60,000$ to $\$ 100,000$ & $-0.081 * *$ & 0.022 & 0.005 & 0.065 & $0.076 * *$ & 0.027 \\
\hline Greater than $\$ 100,000$ & $-0.067 *$ & 0.030 & -0.016 & 0.075 & $0.083 *$ & 0.034 \\
\hline Income unknown & -0.040 & 0.033 & 0.004 & 0.094 & 0.036 & 0.034 \\
\hline \multicolumn{7}{|c|}{ Relative income (Male's income $>$ Female's income) } \\
\hline $\begin{array}{l}\text { Male's income }= \\
\text { Female's income }\end{array}$ & -0.025 & 0.017 & 0.001 & 0.042 & 0.025 & 0.016 \\
\hline $\begin{array}{l}\text { Male's income }< \\
\text { Female's income }\end{array}$ & 0.010 & 0.026 & -0.018 & 0.056 & 0.008 & 0.022 \\
\hline Both incomes unknown & 0.097 & 0.079 & -0.065 & 0.165 & -0.032 & 0.059 \\
\hline
\end{tabular}

Notes: $\uparrow \mathrm{p}<0.1,{ }^{*} \mathrm{p}<0.05$, ${ }^{* *} \mathrm{p}<0.01$. Omitted categories in parentheses. Also included in the regression: female, age, common-law, duration of relation, family type, previously married and language. 
is a difference between official-language groups, it is also important to note that Anglophones in Quebec are also significantly more likely than Anglophones outside Quebec to use a separate approach to income-a difference of 9 percentage points. Hence, the results indicate that income management strategies are correlated with both geographic and linguistic characteristics.

\section{Decomposition analysis}

The greater prevalence of separate-income strategies among common-law than married couples certainly stands out. To gain a clearer perspective of the factors accounting for this difference, a Blinder-Oaxaca decomposition technique is used to estimate the extent to which the between-group difference is attributable to socioeconomic characteristics. It may be, for example, that the prevalence of separate-income strategies among common-law couples simply reflects the shorter duration of these relationships. Results from this decomposition are shown in Table 5.

There is about a 33-percentage-point difference in the use of separate-income strategies between married and common-law couples. Differences in the socioeconomic characteristics of the two groups account for 14 percentage points — or about 42 per cent_ of this overall difference (Table 5). In other words, if the common-law

\section{Table 5. Blinder-Oaxaca decomposition on married or common-law individuals'} use of separate approach to income management.

\begin{tabular}{lc}
\hline & Percentage points \\
\cline { 2 - 2 } Raw difference & 33.5 \\
Explained portion - Total & 14.0 \\
$\quad$ Duration of relationship & 8.3 \\
Family composition & -2.8 \\
Language & 1.7 \\
Quebec & 0.9 \\
Income & 1.2 \\
Prior relationships & 0.8 \\
Sex, age, immigration status and & 1.7 \\
education & 19.5 \\
Unexplained portion &
\end{tabular}

individuals in the sample had the same socioeconomic profile as the married individuals, the difference in the shares using a separate approach to income would decline from 33 percentage points to about 19 percentage points. Duration of relationship plays the largest role, accounting for about 8 percentage points, while family composition accounts for almost -3 percentage points. The fact that a disproportionate share of common-law individuals are Francophones (who are more likely to use a separate approach to income management) accounts for 1.7 percentage points of the difference, while the relatively large share of common-law couples residing in Quebec (where the separation approach is more prevalent) accounts for another 0.9 percentage points. Prior marriages and income characteristics account for another 2 percentage points, while demographic characteristics exert a modest countervailing influence. ${ }^{17}$

17. These decomposition results are based on the coefficients from the sample of married respondents. When coefficients from the sample of common-law respondents are 
Table 6. Blinder-Oaxaca decomposition on Quebec and Rest of Canada individuals' use of separate approach to income management.

\begin{tabular}{lr}
\cline { 2 - 2 } Raw difference & 12.2 \\
Explained portion - Total & 8.2 \\
Language & 5.6 \\
Common-law status & 2.6 \\
Duration of relationship & 0.6 \\
All other variables & -0.6 \\
Unexplained portion & 4.0 \\
\hline
\end{tabular}

The same technique can be used for couples residing in Quebec and the rest of Canada. As shown in Table 6, of the approximately 12 percentage point difference in the prevalence of separate income management strategies, just over 8 percentage points (or 67 per cent) is attributable to differences in the socioeconomic characteristics of the two groups. Language status plays the largest role, accounting for 5.6 percentage points of the 12.2 percentage point difference. Of course, the question of why Francophones are more likely than Anglophones to use a separate approach to income management remains. Attitudes regarding gender roles and values attached to personal independence and autonomy are possible factors that have been included in studies done elsewhere (Vogler and Pahl 1993; Elizabeth 2001; Vogler et al. 2006; Yodanis and Lauer 2007a). The GSS does not contain information on these issues. In addition to language, the greater prevalence of common-law unions in Quebec accounts for 2.6 percentage points (or about one-fifth) of the greater prevalence of separate income strategies in that province. ${ }^{18}$

\section{Conclusions}

In light of the dramatic changes in the characteristics of couples over the last forty years, researchers from a variety of disciplines are re-examining how couples negotiate and manage a wide range of economic activities. The way that couples organize their income can be examined in these terms. While the broad categories used here likely do not capture adequately the complexity of the arrangements that couples use, they are suggestive of the degree of independence involved. The socioeconomic characteristics correlated with the income management strategies are also consistent with this interpretation. Given the focus of this paper on couples aged 45 or older - a group largely characterized by long-term marital unions in which children are or have been present_ - one might reasonably expect income pooling to

used, the results are similar. When one uses "common-law coefficients," compositional characteristics account for 16.7 percentage points, or 50 per cent, of the difference in prevalence of the separate approach (compared with 14.0 percentage points, or 41 per cent, when the "married" coefficients are used). In both approaches, relationship duration accounts for the largest share of the explained component.

18. These decomposition results are based on the coefficients from the sample of respondents living outside of Quebec. When coefficients from the sample of Quebec respondents are used, the explained portion of the difference is somewhat smaller-at 4.8 percentage points or 39.2 per cent of the total difference. This is largely due to the smaller coefficient for the French language dummy estimated from the Quebec sample (0.027) than the rest of Canada sample (0.065). 
be the most prevalent strategy. This is indeed the case, as 57 per cent of respondents pool all their money, with each taking out what he or she needs, and a further 20 per cent pool their income, with one spouse or partner managing and allocating it. The data in this study do not allow us to examine how these strategies correlate with the actual distribution of income between spouses or partners. However, even among older couples, income management strategies are often characterized by a degree of independence, with 23 per cent of the respondents in the sample either partially 8 per cent) or completely (15 per cent) separating their incomes.

The characteristics of the couple relationships matter a great deal in this regard. As often noted in the research literature, separate-income strategies are more prevalent among common-law couples than among married couples-a raw difference of almost 34 percentage points. However, a considerable portion of this difference (42 per cent, or 14 percentage points) is attributable to socioeconomic characteristics that systematically differ between these groups—most notably, the duration of the relationship. The extent to which these characteristics account for between-group differences has not received much attention in the literature. Still, the majority of the married or common-law difference remains unaccounted for in the decomposition. Between-group differences in values and attitudes, such as independence, autonomy, perceived ownership of assets, and expectations regarding the permanence of the relationship, may account for some of this.

The likelihood of using a separate approach to income management is strongly and positively correlated with the wife or female partner's absolute income, but is not with the wife or female partner's income relative to that of her spouse. While resource theory suggests that the relative contributions of spouses are the "key factor promoting more or less equal arrangements [within couples]," with the implication that "when couples earn equal amounts, they are more likely to manage their pooled income jointly" (Yodanis and Lauer 2007a: 1309, 1320), the results from this study do not support this view, as no significant correlation is evident between relative income and income management strategies. Several possible explanations may be advanced for the positive correlation between wife or female partner's absolute income and the use of separate-income strategies, such as greater importance attached to independence or autonomy, desire to maintain control over personal income, and/ or perceived ownership of personal assets among higher-income women. Convenience may also be a consideration, following Treas's finding that couples adopt management strategies, in part, “...to minimize disputes, hassles, and annoyancesthe transaction costs of intimate exchanges" (1993: 732).

The growing number of Canadians in second marriages or blended families raises the question of whether complex families have complex finances. The descriptive results from this study are suggestive of such a relationship, as the share of individuals in blended families using a separate-income strategy is twice as large as the share of individuals in families with children born to both spouses or partners doing so (40 per cent and 17 per cent, respectively). However, the multivariate results indicate that it is the presence of children, regardless of parentage, that is positively associated with income pooling. Readers are reminded that the sample used in this study is restricted to individuals aged 45 or older; a sample of couples in their twenties and thirties may yield different results. The issue of complex families and complex finances is also reflected in the descriptive results from this study, which 
show that individuals with prior marriages are about twice as likely to use a separate-income strategy as individuals with no prior marriages ( 37 per cent and 19 per cent, respectively). This is consistent with the findings in the literature. Again, however, this correlation is non-significant in the multivariate results, perhaps because a broader range of covariates is used here than that employed in most other studies. Interestingly, two of the characteristics most strongly and positively correlated with separate-income strategies-common-law status and women's income-have changed dramatically in recent years. While this might appear suggestive of a trend towards this type of income management strategy, the analysis presented above is based on data from a single point in time, and offers no evidence regarding trends.

Our results underscore the extent to which income management strategies differ between Francophones and Anglophones, and between Anglophones living in Quebec and in the rest of Canada. In short, both geography and language matter. One might point to a number of explanations for these patters, such as differences in attitudes regarding the roles of women and men; differences in the importance attached to values such as personal independence and autonomy; and differences in legal provisions and social institutions. The GSS does not provide information to assess the importance, if any, of these factors.

The organization of income within households has several implications for public policy. ${ }^{19}$ The intra-household distribution of income has implications for the measurement of financial well-being. Measures of low income assume that individuals within families share resources equally and have the same standard of living. Hence, if a family's income is below the low-income threshold, all of its members are identified as living in "straitened circumstances." Because evidence on the intra-family distribution of income is not available, it is not possible to calculate low-income rates differently. However, Phipps and Burton (1995) assessed the sensitivity of low-income rates to different assumptions of intra-family sharing. Using 1992 data, they found that fathers and mothers in two-parent families with children had a low-income rate of 8.9 per cent under the assumption of equal sharing, and that the rate declined to 2.7 per cent for fathers and increased to 17.5 per cent for mothers under an assumption of "minimal sharing." 20 Similarly, Woolley and Marshall (1994) examined the aggregate distribution of household income and reported that an assumption of unequal intra-household sharing ${ }^{21}$ yields a Gini coefficient 27 per cent higher than is yielded by an assumption of equal sharing. The same point applies to income replacement rates among seniors (Larochelle-Coté et al. 2010), as estimates using couples or families as the unit of analysis assume that individuals within those units share the same standard of living, even though the replacement rates achieved by individual family members may differ.

Income management strategies also have implications for the use of tax provisions. For example, couples who view their financial futures as inextricably linked may be more willing than others to contribute their own income into the retirement savings account of their spouse-either inside or outside of Spousal RRSP contribution provisions. Moreover, control by men or by women over the

19. Phipps and Burton $(1995,1996)$ provide a broad discussion of the policy relevance of household approaches to income, underscoring the relevance of new developments in the economics of the family to public policy.

20. Under the assumption that fathers and mothers each keep their own incomes separate.

21. That is, that there is inequality in control over financial flows. 
family finances may influence the level of personal savings. There is a large literature suggesting that men are more likely to spend income under their control, on alcohol and cigarettes, for example. Phipps and Wolley (2008) found that savings can be added to the men's expenditure list. However, they also find that, in cases where women control the family finances, they do not use their control to save for themselves. They found a negative correlation between female control over family finances and both the probability and level of RRSP holdings.

As well, the strategies that couples use to organize and manage their incomes have relevance from a legal perspective. For example, Treas (1993) found that American couples in which husbands are employed in "high-liability medical and legal professions" are more likely than others to use separate bank accounts. Given the elevated risks of such individuals being sued, she argued, couples use separate accounts as a potential defence against litigants. Treas also observed that couples' use of separate bank accounts is lower in states with community property laws (1993: 731), and argued that this is consistent with expectations, since money in separate accounts is not treated as personal property under such legislation. Looking at a small sample of couples in which one or both partners had been married previously, Burgoyne and Morison found that older couples with children from a previous marriage were more likely than others to separate their incomes, and that this was "...especially marked in the way they wished their assets to be treated after their death" (1997: 363). This suggests that, for older individuals in complex family formations, estate planning and the laws governing it are factors influencing the organization of their income.

Using an integrated collective household model, Chiappori et al. (2011) found that changes in alimony rights by province produce important implications for couples in Canada. They find that obtaining the right to petition for alimony upon separation for cohabitating couples led women to reduce their labour force participation as changes in the law increased their power to negotiate within the household. Women in already formed cohabitating couples were more likely to attend school and stop working, and less likely to work full-time, whereas the men were more likely to work and less likely to have work interruptions. These results hold for any cohabitating couples over time but do not apply to individuals who were married, because married couples were already granted these rights before the new legislation. Couples entering a cohabitating relationship after the new laws were affected differently.

Overall, this study provides an opportunity to look at how couples arrange their incomes, and documents considerable variation in this regard. The data used cannot explicitly tell us about how equitably incomes are shared between spouse or partners, or whether there are differences in the living standards of household members. These issues are relevant to public policy, but information remains scarce in this area.

\section{References}

Ashby, K.J., and C.B. Burgoyne. 2008. Separate financial entities? Beyond categories of money management. The Journal of Socio-Economics 37(2):458-80.

Becker, G.S. 1973. A theory of marriage: Part I. Journal of Political Economy 81(4):813-46. 1981. A Treatise of the Family. Cambridge, MA: Harvard University Press.

Belch, M.A., and L.A. Willis. 2002. Family decision at the turn of the century: Has the changing structure of households impacted the family decision-making process? Journal of Consumer Behaviour 2(2):111-24. 
Bonke, J., and M. Browning. 2009. Pooling Income and Sharing Consumption Within Households. Discussion Paper Series 428. University of Oxford.

Bonke, J., and H. Uldall-Poulsen. 2007. Why do families actually pool their income? Evidence from Denmark. Review of Economics of the Household 5(2):113-28.

Bourguignon, F.J., M. Browning, P.-A. Chiappori, and V. Lechene. 1993. Intra-household allocation of consumption: A model and some evidence from French data. Annales d'économie et de statistique 29(janvier-mars):137-56.

Brines, J., and K. Joyner. 1999. The ties that bind: Principles of cohesion in cohabitation and marriage. American Sociological Review 64(3):333-55.

Burgoyne, C.B., and V. Morison. 1997. Money in remarriage: Keeping things simple-and separate. The Sociological Review 45(3):363-95.

Burgoyne, C.B., V. Clarke, J. Reibstein, and A. Edmunds. 2006. 'All my worldly goods I share with you'? Managing money at the transition to heterosexual marriage. The Sociological Review 54(4):619-37.

Burgoyne, C.B., J. Reibstein, A. Edmunds, and V. Dolman. 2007. Money management systems in early marriage: Factors influencing change and stability. Journal of Economic Psychology 28(2):214-28.

Chiappori, P.-A. 1988. Rational household labor supply. Econometrica 56(1):63-90.

Chiappori, P.-A. 1992. Collective labor supply and welfare. Journal of Political Economy 100(3):437-67.

Chiappori, P.-A., and O. Donni. 2006. Les modèles non-unitaires de comportement du ménage : un survol de la littérature. L'Actualité économique, revue d'analyse économique 82(1-2):9-52.

Chiappori, P.-A., B. Fortin, and G. Lacroix. 2002. Marriage market, divorce legislation, and household labor supply. Journal of Political Economy 110(1):37-72.

Chiappori, P.-A., M. Iyigun, J. Lafortune, and Y. Weiss. 2011. Are Intra-Household Allocations Policy Neutral? A Theory and Some Evidence. Duplicated.

Crompton, R., M. Brockmann, and R.D. Wiggins. 2003. A woman's place... employment and family life for men and women. British Social Attitudes: Continuity and Change over Two Decades. British Social Attitudes Survey Series, edited by K. Thomson, J. Curtice, A. Park, L. Jarvis, and C. Bromley. London: Sage Publications.

Dumas, J., and A. Bélanger. 2006. Common-law unions in Canada at the end of the 20th century. Report on the Demographic Situation in Canada, 1996. (Cat. No. 91-209-XIE). Ottawa: Statistics Canada.

Elizabeth, V. 2001. Managing money, managing coupledom: A critical examination of cohabitants' money management practices. The Sociological Review 49(3):389-411.

Fortin, B., and G. Lacroix. 1997. A test of the unitary and collective models of household labour supply. The Economic Journal 107(443):933-55.

Hamplova, D., and C. LeBourdais. 2009. One-pot or two-pot strategies? Income pooling in married and unmarried households in comparative perspective. Journal of Comparative Family Studies 40(3):355-85.

Heimdal, K.R., and S.K. Houseknecht. 2003. Cohabiting and married couples' income organization: Approaches in Sweden and the United States. Journal of Marriage and Family 65(3):525-38.

Kenney, C.T. 2006. The power of the purse: Allocative systems and inequality in couple households. Gender and Society 20(3):354-81.

Kerr, D., M. Moyser, and R. Beaujot. 2006. Marriage and cohabitation in Canada: Demographic and socioeconomic differences in Quebec and Canada. Canadian Studies in Population 33(1):83-117.

Kooreman, P., and A. Kapteyn. 1990. On the empirical implementation of some game theoretic models of household labour supply. Journal of Human Resources 25(4):584-98. 
Larochelle-Coté, S., J. Myles, and G. Picot. 2010. Replacing family income during the retirement years: How are Canadians doing. Analytical Studies Branch Research Paper Series (Cat. No. 11F0019M-No. 328). Ottawa: Statistics Canada.

Marshall, K. 2009. The family work week: Perspectives on labour and income (Cat. No. 75-001X. Vol. 10. No. 4). Ottawa: Statistics Canada.

McElroy, M.B. 1990. The empirical content of Nash-bargained household behaviour. Journal of Human Resources 25(4):559-83.

Milan, A., M. Vézina, and C. Wells. 2007. Family portrait: Continuity and change in Canadian families and households in 2006: 2006 Census. Families and Households, 2006 Census (Cat No. 97-553-XIE). Ottawa: Statistics Canada.

Nyman, C. 1999. Gender equality in 'the most equal country in the world?' Money and marriage in Sweden. The Sociological Review 47(4):766-93.

Pahl, J. 1986. Personal taxation, social security, and financial arrangements within marriage. Journal of Law and Society 13(2):241-50.

Phipps, S.A., and P.S. Burton. 1995. Sharing within families: Implications for the measurement of poverty among individuals in Canada. Canadian Journal of Economics 28(1):177-204.

-1996. Collective models of family behaviour: Implications for economic policy. Canadian Public Policy 22(2):129-43.

1998. What's mine is yours? The influence of male and female incomes on patterns of household expenditure. Economica 65(260):599-613.

Phipps, S., and F. Wolley. 2007. Control over money and the savings decisions of Canadian households. The Journal of Socio-Economics 37:592-611.

Pulkingham, J. 1995. Investigating the financial circumstances of separated and divorced parents: Implications for family law reform. Canadian Public Policy 21(1):1-19.

Samuelson, P.A. 1956. Social indifference curves. The Quarterly Journal of Economics 70(1):1-22.

Tichenor, V.J. 2005. Earning More and Getting Less: Why Successful Wives Can't Buy Equality. Piscataway, NJ: Rutgers University Press.

Treas, J. 1993. Money in the bank: Transaction costs and the economic organization of marriage. American Sociological Review 58(5):723-34.

Vermeulen, F. 2002. Collective household models: Principles and main results. Journal of Economic Surveys 16(4):533-64.

Vogler, C. 1998. Money in the household: Some underlying issues of power. The Sociological Review 46(4):687-713.

Vogler, C. 2005. Cohabitating couples: Rethinking money in the household at the beginning of the twenty-first century. The Sociological Review 53(1):1-29.

Vogler, C., M. Brockmann, and R.D. Wiggins. 2006. Intimate relationships and changing patterns of money management at the beginning of the twenty-first century. The British Journal of Sociology 57(3):455-82.

Vogler, C., C. Lyonette, and R.D. Wiggins. 2008. Money, power, and spending decisions in intimate relationships. The Sociological Review 56(1):117-43.

Vogler, C., and J. Pahl. 1993. Social and economic change and the organisation of money within marriage. Work, Employment and Society 7(1):71-95.

Winkler, A.E. 1997. Economic decision-making by cohabitators: Findings regarding income pooling. Applied Economics 29(8):1079-90.

Woolley, F. 2003. Control over money in marriage. Marriage and the Economy: Theory and Evidence from Advanced Industrial Societies, edited by S.A. Grossbard-Shechtman. Cambridge (UK): Cambridge University Press.

Woolley, F., and Marshall, J. 1994. Measuring inequality within the household. Review of Income and Wealth 40(4):415-31.

Yodanis, C., and S. Lauer. 2007a. Managing money in marriage: Multilevel and crossnational effects of the breadwinner role. Journal of Marriage and Family 69(5):1307-25.

2007b. Economic inequality in and outside of marriage: Individual resources and institutional context. European Sociological Review 23(5):573-83. 